\title{
EXPERIMENTAL STUDY OF LOW CYCLE FATIGUE PROPERTIES FOR EPOXY RESINS WITH DIBUTYL PHTHALATE (DBP)
}

\author{
ZHI WANG ${ }^{* 1,5}$, JIAJIA ZHOU ${ }^{2}$, LINJIAN SONG ${ }^{3}$, LONG LI ${ }^{4}$
}

\begin{abstract}
In order to improve the toughness of traditional epoxy resin, dibutyl phthalate (DBP) was introduced into the epoxy resin. The static mechanical performance of plasticized and unplasticized epoxy resin was evaluated. The test results showed that the DBP modified epoxy resin can obtain a higher toughness than conventional epoxy resin, but the elastic modulus and the tensile strength were slightly reduced. The low cycle fatigue test results indicated that the stress ratio and the stress level were two critical factors of fatigue life, which was increased with the growth of stress ratio. It was also found that the fatigue life of plasticized specimen was much less than that of the unplasticized specimen because of the plastic deformation. A logarithmic linear relationship was then established to predict the fatigue life for plasticized epoxy resin. The strain energy density was also applied to demonstrate the accumulation of energy loss. In addition, the fatigue toughness can be obtained by the hysteresis loop area method.
\end{abstract}

Keywords: Low cycle fatigue, Dibutyl Phthalate (DBP), Epoxy resins, Strain energy, Fatigue life

\footnotetext{
${ }^{1}$ Dr., Zhengzhou University, School of Mechanics \& Engineering Science, No.100 Science Avenue, 450001 Zhngzhou, China, ${ }^{*}$ Corresponding author, e-mail: wangzhi@zzu.edu.cn

${ }^{2}$ Dr., Zhengzhou University, School of Mechanics \& Engineering Science, No.100 Science Avenue, 450001 Zhngzhou, China, e-mail: zhji0771@163.com

${ }^{3}$ Mr., Zhengzhou University, School of Mechanics \& Engineering Science, No.100 Science Avenue, 450001 Zhngzhou, China, e-mail: songlinjian@126.com

${ }^{4}$ Mr., Zhengzhou University, School of Mechanics \& Engineering Science, No.100 Science Avenue, 450001 Zhngzhou, China, e-mail: lilong@gs.zzu.edu.cn

${ }^{5}$ Michigan Technological University, Department of Civil and Environmental Engineering, 1400 Townsend Dr., Houghton 49931, MI, United States
} 


\section{INTRODUCTION}

Epoxy resin has excellent adhesion, mechanical strength, and electrical insulation properties, which can be widely used in electronic material pouring, encapsulation, and coatings [1-2]. Because of its brittle texture and low impact resistance, it was usually necessary to carry out toughening treatment in engineering. From previous studies, glass fiber, carbon fiber, and other materials were added to the epoxy resin matrix to improve the mechanical property [3-4]. However, in this investigation, dibutyl phthalate (DBP) was selected as a modification for improving the mechanical property of conventional epoxy resin [5-6], which can make the products have good flexibility, stability, adhesion, and water resistance by toughening the epoxy resins.

Epoxy resin was also widely used in the field of engineering structure reinforcement. The hydrophilic epoxy resin can be polymerized and cured in the condition of room temperature and high alkaline environment when it is dispersed in water. High strength, good weather resistance and chemical stability could be obtained after the epoxy resin is injected into structural cracks [7-8]. Therefore, the epoxy resin as the matrix of the modified polymer material was extensively used for road repair and structural reinforcement. However, since the brittleness of original epoxy resin, it is not durable upon cyclic loading. Hence, the study on the fatigue behaviour of epoxy resin has an auxiliary effect on the failure mechanism of the structure reinforcement. Due to the brittleness of the pure epoxy resin, there are few studies on the fatigue properties of pure epoxy resin. However, the study on the fatigue properties of the plasticized epoxy resins or epoxy resins matrix material has been repeatedly reported [9-10]. The time-dependent fatigue crack growth behavior of silicon particle reinforced epoxy resin was studied by Alisa [11]. It was found that the crack growth rate $\mathrm{da} / \mathrm{dt}$ was almost independent of the stress level $R$ and frequency $f$ under the constant stress concentration factor $K_{\max }$. Generally, the crack growth behavior was the time variant model of $K_{\max }$ control. Shokrieh studied the influence of the synthesis of graphene and carbon nanofibers on the flexural fatigue properties of epoxy resin cured specimens [12]. The flexural fatigue properties of the cured epoxy resin were significantly increased because of the addition of hybrid nanoparticles. Yang [13] developed a kind of rapid repair epoxy resin binder material and three point bending fatigue tests were carried out on three composite beams with four different stress ratios. The test results showed that this kind of repaired material had a smaller dynamic modulus, which was better than the commonly used epoxy asphalt mixture. Another kind of advanced carbon fiber-flax-epoxy 
resin composite plate was developed by Bagheri [14], which showed a much higher fatigue strength than the conventional plate.

The fatigue property of epoxy resin plays an important role in the reinforcement of structure. The fatigue life of DBP-plasticized epoxy resin was tested and compared with the un-plasticized one. The key factors of the fatigue life of epoxy resin were analyzed, and the effect of toughening on the fatigue properties of epoxy resin was also studied.

\section{EXPERIMENT SCHEME}

The epoxy resin matrix, curing agents and DBP had been mixed by the volume ratio of 6:3:1 for plasticized specimens and fully agitated into the polytetrafluoroethylene(PTFE) mold. The epoxy resin was cured at room temperature and tested after 72 hours. The dimension of the specimen for direct tensile test was determined according to the specification of China, GB/T 1040.1-2006. The specific sample size was shown in Fig. 1. In room temperature of $25^{\circ} \mathrm{C}$ and under atmospheric conditions, the elastic modulus $E$, Poisson's ratio $\mu$ and tensile strength $\sigma_{t}$ of epoxy resin plasticized by DBP was determined through strain test method.



Fig.1. The dimension of specimen. (unit: $\mathrm{mm}$ )

It can be observed from Fig. 2 that the failure morphology of plasticized epoxy resin is very different from the unplasticized one. The fracture of the specimen plasticized by DBP occurred in the middle part of the specimen and a small scale collapse occurred in fracture surface. But the unplasticized resin showed a great brittleness and the specimen was broken into several sections. It is obvious that DBP can increase the toughness of the epoxy resin, but the plasticized resin still has some brittleness. Static mechanical performance test results are shown in Table 1. The elastic modulus and tensile strength of the plasticized specimens are both greatly reduced, and DBP has a small effect on Poisson's ratio. A typical tensile forcedisplacement curve is shown in Fig. 3. It can be seen from the figure that the plasticized resin show more nonlinearity when compared with the unplasticized resin. The measurement results show that the elongation of the plasticized resin and the unplasticized resin are $4.61 \%$ and $3.55 \%$ respectively. 


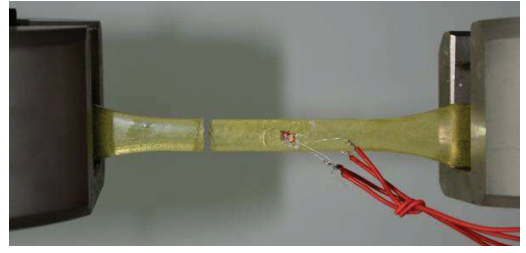

(a)Plasticized epoxy resin

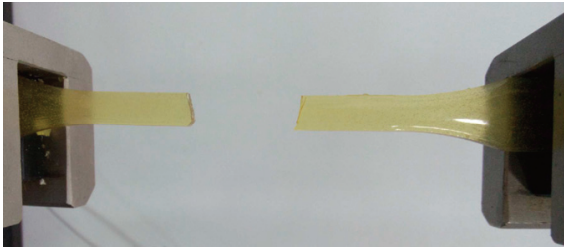

(b)Unplasticized epoxy resin

Fig.2. Typical failure patterns.

Table 1. Effect of DBP on the properties of plasticized epoxy resin

\begin{tabular}{|c|c|c|c|}
\hline & Elastic Modulus $E(\mathrm{GPa})$ & Poisson's ratio $\mu$ & Tensile strength $\sigma_{t}(\mathrm{MPa})$ \\
\hline Plasticized resin & 4.074 & 0.357 & 28.149 \\
\hline Unplasticizedresin & 5.449 & 0.378 & 39.750 \\
\hline
\end{tabular}

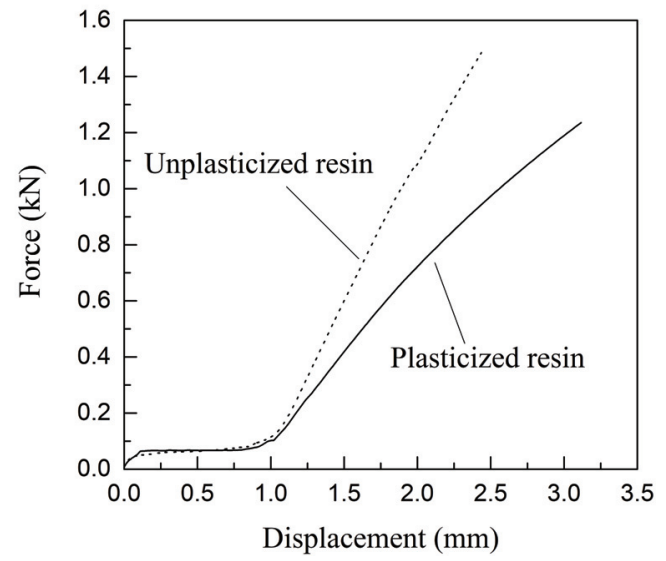

Fig.3. Effect of DBP on the relationship between tensile force and displacement for plasticized epoxy resin

\section{FATIGUE PERFORMANCE TEST}

The same test specimens with the static mechanical test were adopted to carry out equal amplitude low cycle fatigue test under different stress ratio and stress level. The specific experimental control scheme were shown in Table 2 . Where $\sigma_{\min } / \sigma_{\max }$ was stress ratio, $\sigma_{\max } / \sigma_{t}$ was stress level, and $\sigma_{a}=\left(\sigma_{\max }-\sigma_{\min }\right) / 2$ was alternating stress amplitude. A triangle load wave was applied to the specimen under displacement control. 
The test results of fatigue life have been listed in Table 2. It reveals that the stress ratio $\sigma_{\min } / \sigma_{\max }$ and stress level $\sigma_{\max } / \sigma_{t}$ were two most important factors of fatigue life. When the stress level was lower than 0.5 , the fatigue life was more than $10^{5}$ which would be considered as high cycle fatigue. Fatigue life was increased with the increase of stress ratio for both the plasticized resin and unplasticized resin. The greater the magnitude of the load means smaller the fatigue life. However, the fatigue life of plasticized specimen was much less than that of the unplasticized specimen (See Fig.4.). This is because the pure epoxy resin has no obvious nonlinear deformation in the range of the elastic limit. Therefore, the hysteresis loop and damage accumulationis is small correspondingly. After toughening, the static loading process also shows obvious nonlinear deformation and the area of the hysteresis loop is also increased which means faster fatigue damage accumulation rate and shorter fatigue life.

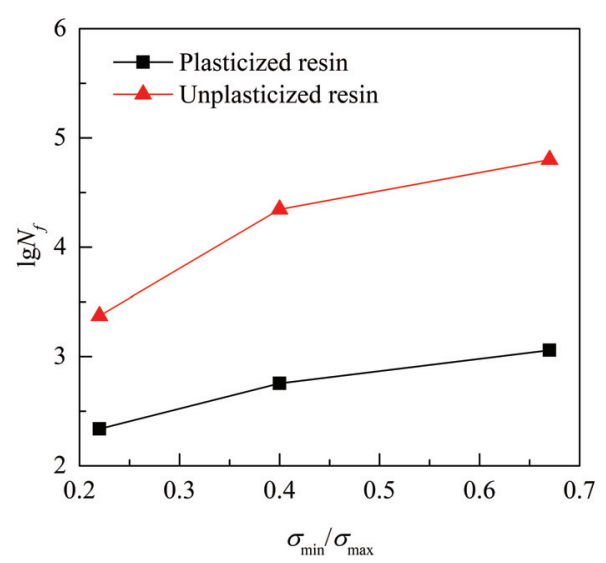

Fig.4 Fatigue life comparison of different stress $\operatorname{ratio}\left(\mu_{\max } / \mu_{\mathrm{t}}=0.8\right)$ 
Table 2. Fatigue specimen parameters and test results

\begin{tabular}{|c|c|c|c|c|c|c|}
\hline & $\sigma_{\max }(\mathrm{MPa})$ & $\sigma_{\text {min }}(\mathrm{MPa})$ & $\sigma_{a}(\mathrm{MPa})$ & $\sigma_{\max } / \sigma_{t}$ & $\sigma_{\min } / \sigma_{\max }$ & $N_{f}($ cycles $)$ \\
\hline \multirow{8}{*}{$\begin{array}{c}\text { Plasticized } \\
\text { expoxy resins }\end{array}$} & 22.5 & 5.00 & 8.750 & 0.80 & 0.22 & 218 \\
\hline & 22.5 & 9.00 & 6.750 & 0.80 & 0.40 & 569 \\
\hline & 22.5 & 15.00 & 3.750 & 0.80 & 0.67 & 1144 \\
\hline & 17.5 & 7.00 & 5.250 & 0.62 & 0.40 & 8171 \\
\hline & 20.0 & 8.00 & 6.000 & 0.71 & 0.40 & 1636 \\
\hline & 7.5 & 5.00 & 1.250 & 0.27 & 0.67 & $>10^{5}$ \\
\hline & 12.5 & 5.00 & 3.750 & 0.44 & 0.4 & $>10^{5}$ \\
\hline & 7.5 & 2.50 & 2.500 & 0.27 & 0.33 & $>10^{5}$ \\
\hline \multirow{3}{*}{$\begin{array}{l}\text { Unplasticized } \\
\text { expoxy resins }\end{array}$} & 31.8 & 7.05 & 12.375 & 0.80 & 0.22 & 2365 \\
\hline & 31.8 & 12.70 & 9.550 & 0.80 & 0.40 & 22181 \\
\hline & 31.8 & 21.20 & 5.300 & 0.80 & 0.67 & 63161 \\
\hline
\end{tabular}

Figure 5 plots the variation of fatigue life with the change of stress level. It can be seen from the figure that fatigue life decrease with the increase of $\sigma_{\max } / \sigma_{t}$. Stress level is one of the most important factor to fatigue life.

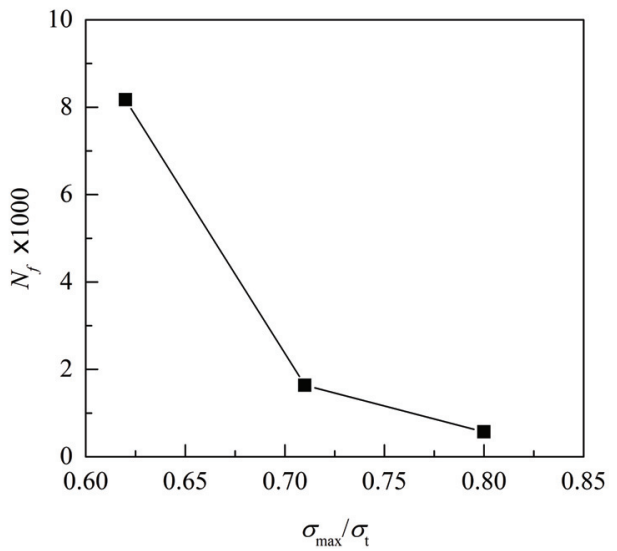

Fig.5 Fatigue life comparison of different stress level $\left(\sigma_{\min } / \sigma_{\max }=0.4\right)$ 
Generally, the relationship between fatigue life $N_{f}$ and stress $\sigma_{\max }$ can be described as follows:

$$
\sigma_{\max }{ }^{m} N_{f}=C, \lg \sigma_{\max }=A+B \lg N_{f}
$$

where: $m$ and $C$ are related to the material properties, specimen shape, stress level and loading mode. $A$ and $B$ are material parameters and $A=\operatorname{lgC} / \mathrm{m}, B=-1 / \mathrm{m}$.

We can check the test data and draw the $\sigma_{\max }-N_{f}$ curve under the double logarithmic coordinate axis. Figure 6 plots the relationship between the fatigue and the stress level. The figure shows that they obey the logarithm linear relation, and we can get the relation after linear fitting:

$$
N_{f}=1.857 \times 10^{17} / \sigma_{\max }{ }^{10.752}
$$

In the fatigue test, the energy is consumed due to the plastic deformation. Most of the energy will be changed into thermal energy which can' t be recovered just like the strain energy. Assuming that the strain energy density during each cycle is $\Delta W_{p}$, which can be measured through the area of the hysteresis loop. The total energy consumed in the fatigue life is equal to the sum of the area of the hysteresis loop. Generally, $\Delta W_{p}$ does not change with the increase of cycle times in a given test. The total strain energy can be described as [15]:

$$
W_{f}=N_{f} \Delta W_{p}
$$

where: $W_{f}$ can be called fatigue toughness, which is related to the properties of materials.

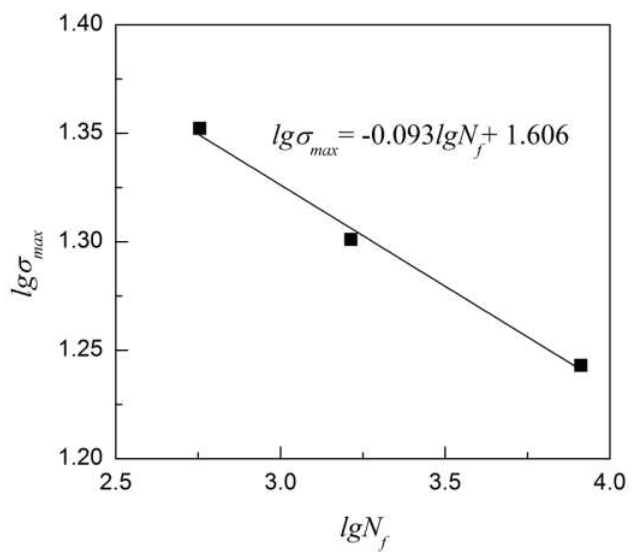

Fig.6 Double logarithm $\sigma_{\max }-\mathrm{N}_{\mathrm{f}}$ curve for plasticized epoxy resin 
Fig. 7 plots a typical hysteresis loop curve and the area around $A C B D$ is the strain energy density. The shaded part of the diagram is the increment of strain energy density $d W_{p}$ and $d W_{p}=\delta \sigma d \varepsilon_{p}$. The total area of the hysteresis loop can be calculated as:

$$
\Delta W_{p}=\int_{\varepsilon_{\mathrm{mon}}}^{\varepsilon_{\mathrm{max}}} \delta \sigma d \varepsilon_{p}
$$



Fig.7 Typical hysteresis loop curve

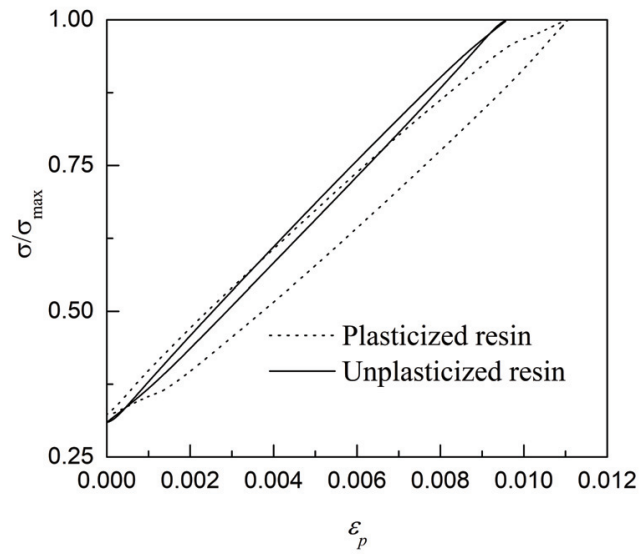

Fig. 8 Hysteresis loop curve of resin under same stress level and stress ratio

It can be seen from Fig. 8 that the strain energy density of plasticized resin is larger than that unplasticized one for the same stress level and stress ratio. It can be explained that the fatigue life of 
unplasticized resin is longer than that of plasticized one in the same fatigue toughness. The fatigue life can be predicted through the total fatigue toughness and hysteresis loop area.

It can be observed from Fig. 9 and Fig. 10 that the area of hysteresis loop and corresponding strain energy density decrease with the increase of stress ratio $\sigma_{\min } / \sigma_{\max }$ for both plasticized resin and unplasticized resin. The strain energy density of plasticized resin is larger than that of unplasticized one for the same stress ratio.

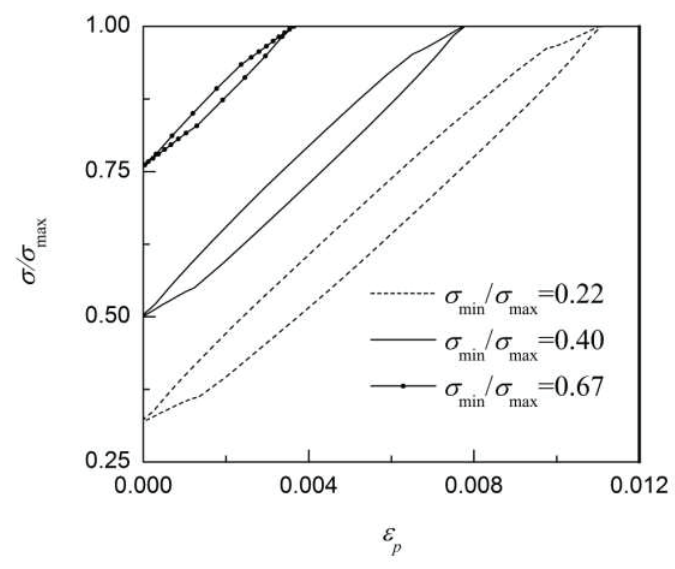

(a)plasticized resin

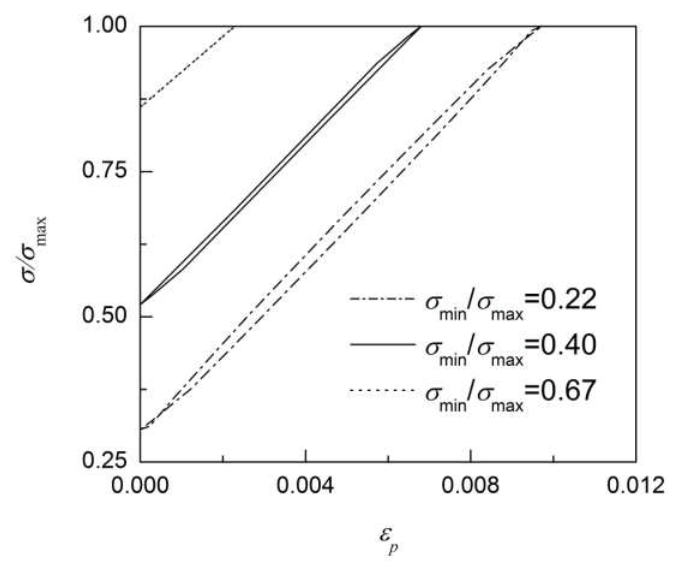

(b)unplasticized resin

Fig.9 Hysteresis loop shape curve of resin under different stress ratio 




Fig.10 Strain energy density under different stress ratio

\section{Conclusions}

In this investigation, the original epoxy resin was plasticzed by dibutyl phthalate (DBP) and the static and fatigue mechanical performance was tested and compared with the results of control samples that made of vrigin epoxy resin. The test results showed that the DBP can increase the toughness and the elongation of the resin but decrease the elastic modulus and tensile strength. The fatigue test results indicated thae the stress ratio and the stress level were the key factors of fatigue life. Fatigue life was improved with the increase of stress ratio. However, the fatigue life of plasticized specimen was much less than that of the unplasticized specimen. A logarithmic linear relationship was proposed to predict the fatigue life of plasticized epoxy resin. The strain energy density was also applied to describe the accumulation of energy loss. At lase, it was found that the fatigue toughness could be obtained by the hysteresis loop area method. The area of hysteresis loop and corresponding strain energy density decrease with the increase of stress ratio for both plasticized resin and unplasticized resin. The strain energy density of plasticized resin is larger than that of unplasticized one for the same stress ratio.

\section{ACKNOWLEDGEMENTS}

This work was supported by the National Natural Science Foundation of China (Grant numbers 51404212); the Foundation for University Key Teacher by the He'nan Educational Committee 
(Grant number 2016GGJS-002) and the program of China Scholarships Council (Grant number 201608410176). We thank Dr. Qingli Dai and Mr. Jiaqing Wang who come from Michigan Technological University for its linguistic assistance during the preparation of this manuscript.

\section{REFERENCES}

1. Junrong Jiang, "Research progress in modification of unsaturated polyester resin", Thermosetting Resin(China) 17:22-25, 2002.

2. Tianxin Ma, Bo Jiang, "Effect of plasticizers on properties of epoxy resin", Thermosetting Resin(China) 18:7-9, 2003.

3. Rui Mei, Jun Wang, Junming Li, Hongxiao Si, "Research on the tension-tension fatigue performance of glass fiber reinforced plastic", Fiber Reinforced Plastics/Composites 2: 39-42, 2013.

4. A-ying Zhang, Dongxing Zhang, Dihong Li, Rui Yang, Haiying Xiao, Jin Jia, "Advances of study on fatigue properties of carbon fiber reinforced epoxy laminates", Fiber Reinforced Plastics/Composites(China) 6: 70-74, 2010.

5. Qiao W, Korai Y, Mochida I, " Preparation of an activated carbon artifact: factors influencing strength when using a thermoplastic polymer as binder", Carbon 39: 2355-2368, 2001.

6. Tarasov A E, Malkov G V, Bubnova M L, "Influence of curing conditions and dibutyl phthalate concentration on the properties of cured epoxy resin", Russian Journal of Applied Chemistry 88: 2015-2020, 2015.

7. Yufen Xie, Xingze Duan, Jianguo Liao, Yishun Zhang, "Research and Application in Coal Mine of Polymer Modified Concrete", Bulletin of the Chinese Ceramic Society 35: 568-572, 2016.

8. Zhi-guo Zhao, Hong Zhu, "Property of expoxy-modified mortar", Concrete(China) 9: 88-90, 2008.

9. Zhenhua Sun, Huiyang Luo, Shiqi Zhao, "Low cycle fatigue behavior of rubber-plasticized epoxy resins", Journal of Tsinghua University(Science and Technology) 39:17-20, 1999.

10. Miyazaki K, Fujii T, Amijima S, "Fatigue properties of single lap joints using rubber plasticized epoxy adhesive - Effect of adhesive thickness on fatigue life", Journal of the Japan Society for Composite Materials 18:151-157, 1992.

11. Alisa Boonyapookana, Anchalee Saengsai, Supachai Surapunt, "Time dependent fatigue crack growth behavior of silica particle reinforced epoxy resin composite", International Journal of Fatigue 87: 288-293, 2016.

12. Shokrieh M M, Esmkhani M, Haghighatkhah A R, "Flexural fatigue behavior of synthesized graphene/carbonnanofiber/epoxy hybrid nanocomposites", Materials \& Design 62: 401-408, 2014.

13. Yang Y, Qian Z, Song X, "A pothole patching material for epoxy asphalt pavement on steel bridges: Fatigue test and numerical analysis", Construction \& Building Materials 94: 299-305, 2015.

14. Bagheri Z S, Sawi I E, Bougherara H, "Biomechanical fatigue analysis of an advanced new carbon fiber/flax/epoxy plate for bone fracture repair using conventional fatigue tests and thermography", Journal of the Mechanical Behavior of Biomedical Materials 35: 27-38, 2014.

15. DANIEL KUJAWSKI, "Fatigue failure criterion based on strain energy density", Journal of Theoretical and Applied Mechanics 27: 15-22, 1989. 


\section{LIST OF FIGURES AND TABLES:}

Fig.1. The dimension of specimen.

Rys. 1. Wymiar próbki.

Fig.2. Typical failure patterns.

Rys. 2. Typowe wzorce uszkodzeń.

Fig.3. Force displacement curve

Rys. 3. Krzywa siła-przemieszczenie

Fig.4. Fatigue life comparison of different stress ratio $\left(\sigma_{\max } / \sigma_{\mathrm{t}}=0.8\right)$

Rys. 4. Porównanie trwałości zmęczeniowej różnych współczynników naprężenia $\left(\sigma_{\max } / \sigma_{\mathrm{t}}=0,8\right)$

Fig.5. Fatigue life comparison of different stress level $\left(\sigma_{\min } / \sigma_{\max }=0.4\right)$

Rys. 5. Porównanie trwałości zmęczeniowej różnych poziomów naprężenia $\left(\sigma_{\min } / \sigma_{\max }=0,4\right)$

Fig.6. Double logarithm $\sigma_{\max }-N_{f}$ curve for plasticized epoxy resin

Rys. 6. Podwójny logarytm $\sigma_{\max }-N_{f}$ krzywej dla plastyfikowanej żywicy epoksydowej

Fig.7. Typical hysteresis loop curve

Rys. 7 Typowa krzywa pętli histerezy

Fig.8. Hysteresis loop curve of resin under same stress level and stress ratio

Rys. 8 Krzywa pętli histerezy żywicy przy tym samym poziomie i współczynniku naprężenia

Fig.9. Hysteresis loop shape curve of resin under different stress ratio

Rys. 9 Krzywa kształtu pętli histerezy żywicy przy różnych współczynnikach naprężenia

Fig.10. Strain energy density under different stress ratio

Rys. 10 Gęstość energii odkształcenia przy różnych współczynnikach naprężenia

Tab. 1. Effect of DBP on the properties of plasticized epoxy resin

Tabela 1. Wpływ DBP na właściwości plastyfikowanej żywicy epoksydowej

Tab. 2. Fatigue specimen parameters and test results

Tabela 2. Parametry próbki zmęczeniowej i wyniki badań 


\section{EKSPERYMENTALNE BADANIE WLAŚCIWOŚCI ZMĘCZENIOWYCH NISKOCYKLOWYCH DLA ŻYWIC EPOKSYDOWYCH Z FTALANEM DIBUTYLU (DBP)}

Słowa kluczowe: zmęczenie niskocyklowe, ftalan dibutylu (DBP), żywice epoksydowe, energia odkształcenia, trwałość zmęczeniowa

\section{STRESZCZENIE:}

$\mathrm{W}$ artykule przedstawiono właściwości zmęczeniowe żywicy plastyfikowanej z ftalanem dibutylu (DBP) oraz niemodyfikowanej żywicy epoksydowej. W celu zwiększenia wytrzymałości tradycyjnej żywicy epoksydowej, do żywicy epoksydowej wprowadzono ftalan dibutylu (DBP). Oceniono statyczną wytrzymałość mechaniczną plastyfikowanej oraz nieplastyfikowanej żywicy epoksydowej. Wyniki badania wykazały, że wydłużenie plastyfikowanej oraz nieplastyfikowanej żywicy wynosi odpowiednio 4,61\% i $3,55 \%$, co oznacza, że modyfikowana żywica epoksydowa z ftalanem dibutylu (DBP) może uzyskać wyższą wytrzymałość niż zwykła żywica epoksydowa. Jednakże moduł sprężystości i wytrzymałość na rozciąganie plastyfikowanej żywicy zostały nieznacznie zmniejszone. Niskocyklowe badanie zmęczeniowe w trzech różnych współczynnikach oraz poziomach naprężenia przeprowadzono w celu porównania wytrzymałości zmęczeniowej żywicy epoksydowej. Wyniki badania wykazały, że współczynnik oraz poziom naprężenia stanowiły dwa krytyczne czynniki trwałości zmęczeniowej, która została zwiększona wraz ze wzrostem współczynnika naprężenia. Stwierdzono również, że trwałość zmęczeniowa plastyfikowanej próbki była znacznie mniejsza niż w przypadku nieplastyfikowanej próbki z powodu odkształcenia plastycznego. Następnie ustalono logarytmiczną zależność liniową, aby przewidzieć trwałość zmęczeniową plastyfikowanej żywicy epoksydowej. Gęstość energii odkształcenia została również zastosowana w celu wykazania nagromadzenia strat energii. Ponadto wytrzymałość zmęczeniową można uzyskać za pomocą metody pola pętli histerezy. Obszar pętli histerezy oraz odpowiednia gęstość energii odkształcenia maleją wraz ze wzrostem współczynnika naprężenia zarówno dla plastyfikowanej i nieplastyfikowanej żywicy. Gęstość energii odkształcenia plastyfikowanej żywicy jest większa niż gęstość nieplastyfikowanej żywicy dla tego samego współczynnika naprężenia. Analiza szkód zmęczeniowych przy użyciu pętli histerezy może być uważana za jedną ze skutecznych metod dla żywicy. 